\title{
The literacy environment of preschool classrooms in three Nordic countries: Challenges in a multilingual and digital society
}

Hofslundsengen, Hilde ${ }^{\mathrm{a} *}$, Magnusson, Maria ${ }^{\mathrm{b}}$, Svensson, Ann-Katrin ${ }^{\mathrm{c}}$, Jusslin, Sofia $^{\mathrm{c}}$, Mellgren, Elisabeth ${ }^{\mathrm{d}}$, Hagtvet, Bente E. ${ }^{\mathrm{e}}$ and Heilä-Ylikallio, Ria ${ }^{\mathrm{c}}$.

${ }^{a}$ Faculty of Education, Arts and Sports, Western Norway University of Applied Sciences, Bergen, Norway; ${ }^{b}$ Department of Education, Linnaeus University, Kalmar, Sweden; ${ }^{c}$ Faculty of Education and Welfare Studies, Åbo Akademi University, Vaasa, Finland; ${ }^{d}$ Department of Education, University of Gothenburg, Göteborg, Sweden; ${ }^{e}$ Department of Special Needs Education, University of Oslo, Norway.

*Hilde Hofslundsengen

$\mathrm{PhD}$

Faculty of Education, Arts and Sports, Western Norway University of Applied Sciences, Campus Sogndal, box 133, 6851 Sogndal, Norway

+4757676059

hilde.hofslundsengen@hvl.no, orcid.org/0000-0001-7092-7387 


\section{The Literacy Environment of Preschool Classrooms in Three Nordic Countries: Challenges in a Multilingual and Digital Society}

This study investigates the physical literacy environment of preschools in three Nordic countries. The environments were assessed using an observation protocol in a total of 131 classrooms with children aged between one and seven in Sweden, Norway and Finland. The results showed that children's books were common and accessible in all three countries. Half of the preschools had a writing centre, and digital devices were available in less than half of them. Multilingual children were present in 82 per cent of the classrooms, but texts and books in the multilingual children's first languages were rare. Taken together, the results suggest that children's books were the main gateway to literacy in these preschools, while artefacts supporting writing skills and digital literacy were less common. The findings indicate that the physical environment in these preschools did not reflect the ongoing societal changes towards increased multimodal literacy.

Keywords: early literacy; preschool quality; literacy environment; Nordic countries; writing centre; multilingualism

\section{Introduction}

The importance of the early years for literacy development is well-known (National Early Literacy Panel, 2008; Whitehurst \& Lonigan, 1998), and the quality of preschool education presumably influences children's learning later in school (Sylva, Chan, Melhuish, Sammons, Siraj-Blatchford \& Taggart, 2011). Building on social democratic values, the tradition of Nordic preschool education operates with a holistic view that emphasizes free play, outdoor life, care, social skills and oral language skills (Hagtvet, 2017). This includes stimulating language awareness as a 'bridge' to reading and writing (Bryant, MacLean, Bradley \& Crosslang, 1990; Frost, 2001; Svensson, 1993). Traditionally, except for shared book reading, Nordic preschools have paid limited attention to children's literacy education (Hagtvet, 2017). More recently, the idea that literacy 'emerges' in preschool has received a considerable amount of research attention, both internationally and in the Nordic countries (Dickinson \& Tabors, 2001; Gustafsson \& Mellgren, 2002; Heilä-Ylikallio, 1997; Teale \& Sulzby, 1986). 
Preschool emergent literacy has been defined as 'the skills, knowledge, and attitudes that are developmental precursors to reading and writing' (Whitehurst \& Lonigan, 1998, p. 848). However, in educational practice, learning to read and write is still associated with schooling, and there is little information on how 'emergent literacy' is currently implemented in Nordic preschools. In the last decade, two ongoing changes have affected Western society: the digital revolution and increasing migration due to work opportunities, family reunifications and the flight of refugees. These changes substantial implications for Nordic education, including literacy education in preschool.

A preschool's physical environment is one of several important indicators of the quality (Dynia et al., 2016); it is also a highly visible, yet unobtrusive, indicator of educational priorities. A preschool's physical environment typically includes books, writing materials, print environment like text and labels, and technological tools (Dynia et al., 2016). Therefore, a classroom's quantity and type of books, the visibility of a writing corner, the presence of digital devices and texts with different orthographic scripts and languages are presumably valid markers of a preschool's emphasis on emergent literacy stimulation. In the current study, we have investigated the physical literacy environments in a Nordic context.

\section{The importance of the physical literacy environment of Nordic preschools}

Children learn through interactions with their peers, teachers (Säljö, 2006), and surroundings, which makes the literacy environment an important part of learning (Gustafsson \& Mellgren, 2002; Sommer, Pramling Samuelsson \& Hundeide, 2011; Svensson, 1993). Different physical artefacts offer different possibilities for learning, both in themselves and through the mediation of a teacher. According to the affordance perspective (Gibson, 1986), the environment of a preschool might invite children and teachers to engage in certain activities related to literacy. In a study investigating 1408 Swedish and Danish preschool teachers' 
views on learning, the interviewees displayed a child-centred approach in which the children's interests, wishes and points of view were paramount when planning activities (Broström, Johansson, Sandberg \& Frøkjær, 2014). However, the educational quality of this child-centred approach could depend on a literacy-rich environment, as the children's initiatives will most likely depend on what is available in their physical surroundings.

The influence of the physical literacy environments on children's literacy conversations and literacy development has been demonstrated in international studies. Neuman and Roskos (1992) added more literacy materials to preschools, such as cookbooks and shopping lists in kitchen play centres, and observed on videos 91 children, aged three to five, in their free play. Comparing the children's free play prior to the intervention in these literacy-enriched settings, the researchers observed significant differences in the frequency of play using literacy artefacts as well as talk about literacy. In a case study including seven preschool children, Worthington and van Oers (2017) investigated how children comprehend literacy. They found that the children used self-initiated play to explore the role and purpose of literacy. The researchers argued in favour of a literacy-rich environment, with various artefacts and graphical signs to use in play. Furthermore, the physical literacy environment appears to be especially important in encouraging children to explore writing (Gerde, Bingham \& Wasik, 2012; Guo, Justice, Kaderavek \& McGinty, 2012). Guo et al (2012) found an interdependent relationship between the physical literacy environments and preschool teachers' interactions with children when supporting early literacy development, suggesting that a rich physical literacy environment might enhance interactions in reading and writing and vice versa.

Few studies have investigated the physical literacy environments of Nordic preschools. However, print environments have been researched in Sweden. Margrain and Mellgren (2015) noted the importance of using signs and symbols in the print environment to 
make it easier for children to understand meanings and engage in literacy learning. Further, in a study of 28 Swedish preschool classrooms, Gustafsson and Mellgren (2002) identified different ways in which print and text in the physical environment invited children to explore texts. In some preschools, the print environment invited children to do so with the exhibited texts through pictures, signs, symbols and words in a communicative narrative way, while other print environments did not invite to these interactions and were as such more passive.

\section{The consequences of the digital revolution on early literacy education}

In the past decade, society has become increasingly mediated and informed by digital technology (Wessels, 2007), but its role in preschool education is unclear and should be carefully considered. Digital devices are common in the lives of young children (Kazakoff, 2014; Palaiologou, 2016). For instance, in Sweden in 2016, five per cent of children aged under one used the internet daily, mostly with tablet applications (Swedish Media Council, 2017). A Norwegian study (Norwegian Media Authority, 2014) found that $66 \%$ of children between one and four years used the internet at home, and that the number of preschool children using internet was increasing. Additionally, Finnish statistics on children's media usage from 2013 show that more than $90 \%$ of the children under eight used the internet occasionally (Suoninen, 2013). Hence, Nordic children are frequent technology users at home.

Digital devices have found their way into early childhood education (Good, 2005; Lafton, 2015), and among preschool teachers, there are both advocates and opponents of using digital technology in the classroom (for example, see Fast, 2007; Lindahl \& Folkesson, 2012). Research has shown that the integration of digital devices in preschools is a slow and complex process (Inan \& Lowther, 2010; Palaiologou, 2016). Many factors affect this integration, such as economic conditions (Fast, 2007) and teachers' agency to act in accordance with their own pedagogical beliefs (Lindahl \& Folkesson, 2012; Palaiologou, 
2016). Inan and Lowther (2010) found that the technological integration is positively affected by a high availability of computers, which accords with the concept of affordance (Gibson, 1986). Available digital devices might be an invitation for preschool teachers and children to use them, but some studies have shown that, regardless of access to computers and tablets, the meaningful use of digital devices is limited in classrooms and early literacy education (Inan \& Lowther, 2010; Merchant, 2008; Wohlwend, 2009). Ultimately, research shows that technology can contribute to learning by making it more social and collaborative and by promoting language and literacy (Falloon, 2013; Good, 2005; Jenkins, Clinton, Purushotma, Robison \& Weigel, 2006), which provides evidence in support of its use in early childhood education. Development of digital resources takes place at such a fast way that it is difficult to keep up with research on it. However, the digital resources have to be available in preschools as well as print, books and other tools like paper, pens and crayons. Regardless of what medium children uses to communicate and express themselves, availability and interaction are of importance in preschool.

\section{Multilingual classrooms}

Due to the ongoing trend of human mobility, we can expect more multilingual children in preschools. The increasing number of multilingual children in preschools challenges preschool teachers to rethink their monolingual pedagogical strategies (cf. Cummins, 2007). Bilingualism has been found to improve the development of a child's identity and cognitive ability (Creese \& Blackledge, 2010; Cummins \& Persad, 2014; Garcia \& Lin, 2016). Using the potential of children highlights the teacher's role in supporting the 'whole child' (translanguaging, see Garcia \& Wei, 2014; Gort \& Sembiante, 2015). Consequently, it is important for preschool teachers to support bilingual children's second language (L2) education in order to facilitate communication and engagement in preschool and to prepare 
children for further schooling (Melby-Lervåg \& Lervåg, 2014). Additionally, L1 should naturally be part of the preschool classroom.

Finland has two official languages, Finnish and Swedish, implying that a high degree of bilingualism already exists there. However, in the last decade, bilingualism and multilingualism have become common in all three Nordic countries investigated in this study. The Swedish School Inspectorate (2017) found that preschool teachers support the development of Swedish well but rarely encourage multilingual children to use their first language (L1) in daily activities. Teachers presumably lack_strategies and knowledge necessary for the creation of a multilingual practice. Studies have shown that when this is the case, teachers sometimes view children diverting from the language of instruction as an indication of ignorance and expect less of them (Bunar, 2015; Lindberg, 2011; Torpsten, 2011). As there could be many different language-speakers in a classroom, it is difficult to provide explicit educational support for the L1 of every child. However, Cummins et al. (2005) argue that by welcoming a child's L1 into the classroom, teachers can demonstrate that the preschool believes in the importance of multilingualism and thereby supports the bilingual child's identity. One way of welcoming children's L1 could be by including the print and books of the children's L1 in the physical environment, for example by having a sign on the front door wishing welcome in each of the preschool group children's L1.

\section{The current study}

The central aim of the current study was to investigate how literacy is supported in Nordic preschools, as reflected in the physical environment of classrooms. Our overarching research question was: What characterizes the preschool literacy environment in the three Nordic countries studied? To answer this question, the study made use of a structured observation protocol that assessed the frequency of elements in the physical literacy environment. To 
simplify the observations, we investigated the physical environment of three areas of literacy: 'print literacy' (e.g. books and print), 'digital literacy' (e.g. digital devices) and 'multilingual literacy' (e.g. books and print in other languages than the language of instruction).

Our investigation included preschools from Sweden, Norway and Finland. Comparative research within the Nordic countries is interesting due to the unique combination of similarities and differences between all three countries. They share basic social democratic values, similar preschool curricula, and a generally high level of preschool structural quality, for example, the ratio of teachers to children (Hagtvet, 2017). However, there are also important differences in languages and orthographic transparency, experiences of immigration, and reading cultures, among others. We would expect that any differences in the physical environment of preschools in the current study most probably reflect influences from the factors that differentiate among the countries. In the following, we will describe the preschool system in each country.

In Sweden, 85 per cent of the children aged between one and five are enrolled in preschools (Swedish Ministry of Education, 2016a). Children often attend preschool from the age of one and most Swedish children spend large part of the day there. Formal literacy education begins when the children turn seven and attend compulsory school. In the preschool curriculum, oral language learning is highlighted, and children with a L1 other than Swedish have the opportunity to develop both Swedish and their L1 (Swedish Ministry of Education, 2016b). Early literacy is included in the language and communication curriculum where its link to identity and learning is emphasised. There is a long tradition of shared book reading in Swedish preschools. The curriculum encourages preschool teachers to promote children's interest in the written language and to enhance their understanding of symbols and signs, as well as pictures, texts and other media (Swedish Ministry of Education, 2016a). 
In the Norwegian preschool system, 91 per cent of children aged between one and five attend preschool (Statistics Norway, 2016). Formal literacy education starts when the child attends school at the age of six. Language learning is highlighted as a central task of preschool education, and there is a long-standing tradition of shared book reading. In the latest preschool curriculum (Norwegian Ministry of Education, 2017, p. 47), early literacy activities are emphasized, and the teachers are encouraged to support the children's explorations of- and experience with different types of literacy activities such as language awareness, writing and reading. The curriculum further states that the preschool learning environment should include digital devices, but it also states that they should be used carefully under adult supervision, and not as a main method of work. With regard to multilingualism, the Norwegian curriculum states that preschools should support multilingual children in using L1, and help with their acquisition of L2 actively. Furthermore, 16 per cent of the population have a L1 other than Norwegian (Statistics Norway, 2017).

Attendance in the Finnish formal preschool system is lower than in many OECD countries, and much lower than in Sweden and Norway. Altogether, 28 per cent of children under three and 68 per cent of those aged from three to five attend preschool (OECD, 2016). In Finland, formal literacy learning begins when the child starts school at the age of seven, but language learning is highlighted as one of the main tasks of preschool education. Education, books and shared reading activities are praised in Finland. The latest preschool curriculum, implemented in August 2017, strongly emphasizes early literacy activities that support language awareness. Compared with earlier curricula, in which ICT and digital devices were not mentioned, the 2017 curriculum insists upon the use of- and access to digital devices (Finnish National Agency for Education, 2016). The curriculum further states that preschools should support bilingual children in using their L1 and actively help with their acquisition of L2. Finland has two national languages, Finnish and Swedish; the latter is the L1 of 5.3 per 
cent of the population, but many more are bilingual. In addition, 6.4 per cent of the population have an L1 other than Finnish and Swedish (Statistics Finland, 2017).

To sum up, the curricula in the three countries underscore to various degrees the importance of supporting children's literacy. However, to the best of our knowledge, no study has yet investigated how these aims are reflected in the physical environments in Nordic preschools from a comparative perspective.

\section{Method}

\section{Participants}

We conducted an observation study of physical literacy environments in preschools in three regions: The Swedish east coast, the Norwegian west coast and the Finnish west coast. Invitations to participate in the current study were mainly sent to preschools that participated in preschool teacher training periods. The only exception was the Finnish speaking preschools, which were randomly selected. Overall respond rate from the preschools were high $(82 \%)$. The high respond rate may be because the information about the project was given both through email and in face-to-face meetings with the preschools. Another explanation could be the fact that there were no sensitive data collected as we just observed the classroom environment. The sample comprised 131 preschool classrooms: 35 in Sweden, 45 in Norway and 51 in Finland. Many of the Finnish preschools participating in this study were located in bilingual municipalities with either Finnish or Swedish as the majority language (both are national languages in Finland). The average group size of each preschool class was 20 ( $S D=4.6$, range 11-38). The groups included children aged between one and seven, but a majority of the classrooms (63\%) included children aged from three to six. In the Swedish preschool classrooms, the average number of teachers was the highest of the three countries, and the average number of teacher assistants was the lowest. Table 1 shows the 
average numbers of preschool teachers and other staff per classroom of the three samples.

[Table 1 here]

In 82 per cent of the preschool classrooms, the groups included multilingual children with an L1 other than the countries' national languages, to whom we will refer simply as 'multilingual children'. In 76 per cent of the Finnish preschools, there were Swedish-Finnish bilingual children $(M=3$, range 1-12). There were multilingual children in 86 per cent of the Swedish preschools, 93 per cent of the Norwegian preschools and 69 per cent of the Finnish preschools, with an average of three multilingual children per group $(S D=2.7$, range $1-14)$. Extra support in multilingual children's L1 was offered in 12 per cent of the preschools that included multilingual children. More specifically, 23 per cent of the Swedish, 10 per cent of the Norwegian and 6 per cent of the Finnish preschools offered this kind of support. Altogether, 33 per cent of preschools with multilingual children offered extra support in the L2. However, this varied between the samples: 3 per cent of Swedish preschools, 57 per cent of Norwegian preschools and 23 per cent of Finnish preschools offered support in the L2. There were significant differences between Swedish and Norwegian preschools $(\chi 2(1,72)=$ $22.35, p<.001, \varphi=.56)$ and between Norwegian and Finnish preschools $\left(\chi^{2}(1,55)=4.61, p\right.$ $<.05, \varphi=-.29$ ) in extra support for L2, with Norwegian preschools providing more support.

\section{Design and Measures}

To get information about the physical environment as unobtrusively as possible, an observation protocol was designed for the purpose, inspired by earlier studies by Gustafsson and Mellgren (2002), Svensson (2009), and the third edition of the Early Childhood Environmental Rating Scale, ECERS-3 (Harms, Clifford \& Cryer, 2014). The observation protocol was designed with tick off boxes and spaces to write. The protocol was translated into Swedish, Norwegian and Finnish. 
The observation protocol comprised two parts: information about the preschool classroom (e.g. information about the staff and the number and age of the children), and investigation of the physical environment of the preschool classroom (see Appendix I). The physical environment included three themes: (a) 'print literacy', (b) 'digital literacy', and (c) 'multilingual literacy'. The questions regarding (a) 'print literacy' focused on the number of books, their availability, the presence, or lack of, a reading area and the availability of audiobooks. Books were considered 'visible' if they were visible to the children, e.g. on a bookshelf. A reading area was defined as a secluded place, separated from active and loud play, in which children could read books independently or with others. A writing centre was defined as a place designed for children's writing, e.g. with pens and papers. The questions also included information about written signs and texts on the walls, informational labels or signs placed on shelves and boxes, nametags and texts on the wardrobes, and graphic symbols, for example, smileys, numbers and arrows. The questions about (b) 'digital devices' included information about computers, tablets and interactive writing boards available for children. The third theme (c), 'multilingual literacy', regarded the presence of languages other than the language of instruction, for example, on print on the walls, in books and other types of text. It must be noted that the observation protocol only focused on the physical environment, and not children's development or interactions between adults and children or between peers.

\section{Procedure and statistical analyses}

All participating preschools gave informed consent prior to the observation, and researchers and trained research assistants carried out the observations. The research assistants were trained in using the observation protocol by the authors prior to starting. Some answers in the protocol were unfortunately left unanswered and we handled the missing data by imputing 
missing values using the expectation-maximisation (EM) algorithm (Dempster, Laird \& Rubin, 1977). However, missing data on audiobooks, name signs, writing centre and extra support in L2 were not missing at random and therefore not imputed. The actual sample sizes are marked in Table 2. The data analyses were performed in IBM SPSS version 24 using descriptive statistics, one-way independent analysis of variance (ANOVA) with post-hoc tests of Games-Howell (due to differences in sample sizes), Chi-Square tests (because the variables were binary) and a bivariate Spearman correlation.

\section{Results}

The results are divided into two sections: first, the descriptive information about the observed literacy artefacts, and second, the interrelationships between them. We present the general results from all three countries and note any significant differences between them.

\section{The physical environment}

The descriptive statistics from the findings concerning the literacy artefacts are presented in Table 2. The average number of books that children had direct access to was 63 ( $S D=70.4$, range $=0-400)$; Sweden: $41(S D=26.77)$, Norway: $38(S D=28.64)$ and Finland $97(S D=$ 95.95). This rather large number indicates that, in most preschools, children could independently access books whenever they wanted. A one-way ANOVA analysis revealed that there were significant differences between the three countries in the numbers of available books $(F(2,122)=11.70, p<.001)$ : post-hoc analyses showed that there were significantly more books in the Finnish preschools than in the Swedish $(p<.001)$ and Norwegian preschools $(p<.001)$. Audiobooks were available in half of the preschool classrooms.

Almost all the classrooms had children's nametags placed on the wardrobe. There were significant differences in the prevalence of other signs or labels in the print environments. Swedish preschools had fewer signs than both Norwegian $\left(\chi^{2}(1,80)=\right.$ 
17.07, $p=.001, \varphi=.46)$ and Finnish preschools $\left(\chi^{2}(1,86)=18.40, p<.001, \varphi=.46\right)$. Both the alphabet and other symbols were commonly displayed in the print environments of the preschools. Half of the classrooms had a writing centre. There were significant differences between the three countries in the availability of writing centres, with Swedish preschools having more than Norwegian $\left(\chi^{2}(1,80)=6.20, p<.05, \varphi=-.28\right)$ and Finnish preschools $\left(\chi^{2}\right.$ $(1,86)=11.58, p<.001, \varphi=-.39)$.

Digital devices were available for children in less than half of the preschool classrooms. There was a significant difference in access to digital devices between Swedish and Finnish preschools $\left(\chi^{2}(1,86)=9.47, p<.01, \varphi=-.33\right)$, with the former having more digital devices than the latter.

In classrooms with multilingual children, 14 per cent of the preschools had books in the multilingual children's L1. There were no significant differences between the countries in the number of books $(F(2,128)=1.04, p<.355)$. In the print environment, texts in other languages than the countries' national languages were found in $20 \%$ of the classrooms. There were no significant differences between the countries.

[Table 2 here]

\section{Relationship between the literacy artefacts in the physical environment}

Table 3 displays the correlations between literacy artefacts in the preschools. There were generally low correlation values and few of them were significant. In the area of 'print literacy' there was a small but significant relationship between number of books and the presence of visible books, between the number of books and the presence of symbols, and between the presence of visible books and the presence of symbols. Furthermore, there were small positive correlations between the presence of writing centres and visible books, reading areas and alphabets. There were no correlations between the use of signs and nametags. In the 
area of 'digital literacy', there was a medium positive correlation between the availability of digital devices and audiobooks, and a small positive correlation between the availability of digital devices and the presence of displayed alphabets. Alphabets correlated also positively with audiobooks.

[Table 3 here]

\section{Discussion}

This study investigated the ways in which literacy was supported in Nordic preschools, as reflected in the physical environment of the classrooms. The main findings were that different aspects of literacy were present to various degrees in different classrooms, and in some cases, differences between countries were also observed. As for 'print literacy', the environments could be characterized as literacy-rich, but there was a low occurrence of literacy artefacts more characteristic of contemporary society, for example in the availability of digital devices and signs of multi-lingual literacy.

Books were a dominant part of the physical literacy environment of almost all preschools. However, the quantity of available books varied between the countries. The Finnish preschools had significantly more books than the Swedish and Norwegian ones, suggesting that reading books plays a particularly important role in the Finnish preschool practice. In international rankings, Finnish schoolchildren achieve top ranking literacy scores and considerably higher scores than Norwegian and Swedish pupils (OECD, 2017). The advanced reading skills of Finnish students have been attributed to the significant role of reading in the Finnish tradition and culture (Leppänen, Niemi, Aunola, \& Nurmi, 2004). Our findings suggest that Finland's reading culture is strong already in early preschool practices. Even though most of the Nordic preschools had many books, less than half had a secluded reading area. Secluded and undisturbed reading areas are important, as they promote opportunities for holding dialogues to support children's communication or quietly 
concentrating on the content of the literature (Roskos \& Neuman, 2011; Simonsson, 2004).

Another prominent finding is the observation of great variation in print environment and writing artefacts. The children received constant logographical input, as some signs, symbols and pieces of text were displayed in almost all classrooms. Several studies have found that the print environment and its components can affect literacy development (e.g. Gustafsson \& Mellgren, 2002; Justice, Kaderavek, Fan, Sofka \& Hunt, 2009; Magnusson, 2013; Mellgren \& Margrain, 2015); it is therefore important to consider the use of print and signs when planning the literacy environment. Furthermore, only half of the preschools had a dedicated writing centre, although it was more frequent in Swedish than in Norwegian and Finnish preschools. This apparent dearth of writing centres is in accordance with Gerde et al.'s (2012) finding that writing activities were underrepresented and even non-existent in some preschool classrooms. These findings suggest that many teachers do not encourage preschool children's writing, even though both developmental and interventional research show that early writing in preschool facilitates later learning to read and write in primary school (Hofslundsengen, Hagtvet, \& Gustafsson, 2016; Martins, Albuquerque, Salvador, \& Silva, 2013; Ouellette \& Sénéchal, 2008). Many children spontaneously explore the alphabetic code and written language through writing in preschool, and physical areas that invite them to write might reinforce their motivation for doing so. However, writing activities are not bound necessarily to a writing centre; the environment as a whole plays an important role in offering children possibilities to explore their writing skills (e.g. Guo et al., 2012; Worthington \& van Oers, 2017).

One rather unexpected finding was the generally low availability in the physical environment of multilingual literacy such as signs and texts in the first language of children with a minority language background. In other words, the physical environment did not reflect the multilingual reality of these preschools, as the majority included multilingual children. 
Regarding digital literacy, the main impression was a pattern of low availability to the effect that the digital revolution in society was not reflected in these preschools. In fact, many preschools had no digital devices available for the children to use at all. This observation is in accordance with studies carried out outside the Nordic countries, where it was similarly found that digital devices are rarely available in preschools (Inan \& Lowther, 2010; Merchant, 2008; Wohlwend, 2009). This is a noteworthy observation, since digital devices may be beneficial not only to the development of literacy, but also to a broad range of skills in a digital society (Falloon, 2013; Good, 2005; Jenkins et al., 2006). This finding invites increased research focus on the role of digital literacy in preschools, for example specific research on how preschools may support digital competence in ways that are beneficial to preschool children. It also raises questions concerning the strategy of stakeholders and policymakers for the induction of young children into the digital society. Curricula and policy documents address the issue of digital devices to various degrees in Finland, Norway and Sweden (see Finnish National Agency of Education, 2016; Norwegian Ministry of Education, 2017; Swedish Ministry of Education, 2016b). Interestingly, Sweden seems to be in the vanguard when it comes to using digital devices, despite not mentioning them in the Swedish curriculum, suggesting that the relationship between regulations and practice is not obvious. Other possible explanations for the low availability of digital tools are lack of economic resources (Fast, 2007; Niikko \& Havu-Nuutinen, 2009). Also, preschool teachers' pedagogical views on the role of digital devices as something that does not belong in preschool (Lindahl \& Folkesson, 2012), and lack of digital competence among the staff in how to support digital literacy in preschool children at different age levels could be additional explanations. One point worth highlighting is that mere availability of digital devices does not guarantee their meaningful use. Therefore, more research is needed to better understand how to use digital 
technology in preschools in ways that are beneficial to children's literacy development at different age levels.

Overall, there were more similarities than differences between the preschools in our study. This may reflect the many similarities in culture and traditions across borders, and, to some extent, probably also the relatively similar curricular approaches (Hagtvet, 2017; Vallberg Roth, 2014).

\section{Limitations}

This study has four limitations. First, the small sample size invites caution if generalizing conclusions are drawn from the findings. The differences observed could be regional, rather than national. The sample only included preschools in defined areas of Sweden, Norway and Finland; hence, it is not in statistical terms representative of a larger Nordic area, or of national trends. Second, even though the research assistants have been trained prior to observation, the observations were not crosschecked, as only one person conducted the observation per preschool. Third, there were some missing data in the sample. However, this was corrected by imputing missing values using the expectation-maximisation (EM) algorithm (Dempster, Laird \& Rubin, 1977). Finally, our study is also limited in the fact that it do not examining the relation between the physical literacy environment and children's actually early literacy development.

\section{Implications and conclusions}

This study contributes to the knowledge about physical literacy environments in Nordic preschools, and its findings hold implications for preschool practice. Based on Gibson's (1986) concept of affordance, we have studied the availability of literacy artefacts in the physical preschool environment on the assumption that these are used to support children's literacy development. Physical literacy environments may influence children's literacy 
development (Guo et al., 2012; Gustafsson \& Mellgren, 2002; Neuman \& Roskos, 1992; Sommer et al., 2011), as they are essential in providing supportive and educative surroundings for the children, especially for children who lack early literacy support at home (Teale \& Sulzby, 1986). Hence, the physical literacy environment needs to be thoroughly planned by the teacher in order to support the literacy development in a broad variety of children. Our findings suggested that print literacy in terms of children's books and a fair amount of print artefacts such as signs and written texts were well represented in the physical environments of these preschools. However, digital literacy and multilingual literacy were not incorporated in the physical literacy environment. These findings suggest that physical literacy environments need more attention in practice. Also, more research is needed to determine how preschools' physical environments may be used in early literacy practices to the best interest of all the children involved. 


\section{References}

Bunar, N. (2015). Nyanlända och lärande: Mottagning och inkludering. [Newly arrived and learning: Reception and inclusion]. Stockholm, Sweden: Natur och Kultur.

Broström, S., Johansson, I., Sandberg, A., \& Frøkjær, T. (2014). Preschool teachers' view on learning in preschool in Sweden and Denmark. European Early Childhood Education Research Journal, 22(5), 590-603.

Bryant, P. E., MacLean, M., Bradley, L. L., \& Crossland, J. (1990). Rhyme and alliteration, phoneme, detection, and learning to read. Developmental Psychology, 26(3), 429-438.

Creese, A., \& Blackledge, A. (2010). Translanguaging in the bilingual classroom. A pedagogy for learning and teaching. The Modern Language Journal, 94(1), 103-115.

Cummins, J. (2007). Rethinking monolingual instructional strategies. Canadian Journal of Applied Linguistics, 10(2), 221-238.

Cummins, J., Bismilla, V., Chow, P., Cohen, S., Giampapa, F., Leoni, L., Sanhu, P., \& Sastri, P. (2005). Affirming identity in multilingual classrooms. The Whole Child, 63(1), 3843.

Cummins, J., \& Persad, R. (2014). Teaching through a multilingual lens: The evolution of EAL policy and practice in Canada. Education Matters, 2(1), 3-40.

Dempster, A. P., Laird, N. M., \& Rubin, D. B. (1977). Maximum likelihood from incomplete data via the EM algorithm. Journal of the Royal Statistical Society, Series B, 39(1), 138.

Dickinson, D. K., \& Tabors, P. O. (2001). Beginning literacy with language: Young children learning at home and school. Baltimore, USA: Brookes Publishing.

Dynia, J. M., Schachter, R. E., Piasta, S. B., Justice, L. M., O’Connell, A. A., \& Pelatti, C. Y. (2016). An empirical investigation of the dimensionality of the physical literacy environment in early childhood classrooms. Journal of Early Childhood Literacy, 115.

Falloon, G. (2013). Young students using iPads: App design and content influences on their learning pathways. Computers \& Education, 68, 505-521.

Fast, C. (2007). Sju barn lär sig läsa och skriva. familjeliv och populärkultur i möte med förskola och skola [Seven children learn to read and write. Family life and popular culture in contact with preschool and primary school] (Doctoral dissertation). Uppsala: Acta Universitatis Upsaliensis. 
Finnish National Agency of Education. (2016). Grunderna för planen för småbarnspedagogik 2016. [National core curriculum for early childhood education and care]. Retrieved from:

http://www.oph.fi/download/179348_grunderna_for_planen_for_smabarnspedagogik_ 2016.pdf

Frost, J. (2001). Differences in reading development among Danish beginning-readers with high versus low phonemic awareness on entering grade one. Reading and Writing: An Interdisciplinary Journal, 14(7), 615-642.

Garcia, O., \& Lin, A. M. Y. (2016). Translanguaging in bilingual education. In O. García, A. M. Y. Lin, \& S. May (Eds.), Bilingual and multilingual education (pp. 117-130). Springer.

Garcia, O., \& Wei, L. (2014). Translanguaging: Language, bilingualism and education. New York: Palgrave Macmillan.

Gerde, H. K., Bingham, G. E., \& Wasik, B. A. (2012). Writing in early childhood classrooms: Guidance for best practices. Early Childhood Education Journal, 40(6), 351-359.

Gibson, J. J. (1986). The ecological approach to visual perception. New York, USA: Taylor \& Francis Group LLC.

Good, L. (2005). Snap it up! Using digital photography in early childhood. Childhood Education, 82(2), 79-85.

Gort, M., \& Sembiante, S. F. (2015). Navigating hybridized language learning space through translanguaging pedagogy: Dual language preschool teachers' languaging practices in support of emergent bilingual children's performance of academic discourse.

International Multilingual Research Journal, 9(1), 7-25.

Guo, Y., Justice, L. M., Kaderavek, J. N., \& McGinty, A. (2012). The literacy environment of preschool classrooms: contributions to children's emergent literacy growth. Journal of Research in Reading, 35(3), 308-327.

Gustafsson, K., \& Mellgren, E. (2002). Using text in pre-school: A learning environment. Early Child Development and Care, 172(6), 603-624.

Hagtvet, B. E. (2017). The Nordic countries. In Kucirkova, N., Snow, C. E., Grøver, V., \& McBride (Eds). The Routledge international handbook of early literacy education. A contemporary guide to literacy teaching and interventions in a global context (pp.95111). London, UK: Routledge 
Harms, T., Clifford, R., \& Cryer, D. (2014). Early Childhood Environmental Rating Scale (ECERS-3). New York: Teachers College Press.

Hofslundsengen, H., Hagtvet, B. E., \& Gustafsson, J. E. (2016). Immediate and delayed effects of invented writing intervention in preschool. Reading and Writing: An Interdisciplinary Journal, 29(7), 1473-1995.

Heilä-Ylikallio, R. (1997). Vad berättar barntexter? Mönster i texter skrivna av barn i åldern sex och åtta år. [What do children's texts tell? Patterns in texts written by six-and eight-year-old children]. (Doctoral dissertation). Åbo: Åbo Akademis förlag.

Inan, F. A., \& Lowther, D. L. (2010). Factors affecting technology integration in K-12 classrooms: A path model. Educational Technological Research and Development, $58(2), 137-154$.

Jenkins, H., Clinton, K., Purushotma, R., Robison, A. J., \& Weigel, M. (2006). Confronting the challenges of participatory culture: Media education for the 21 st century. MacArthur Foundation Publication, 1(1), 1-59.

Justice, L. M., Kaderavek, J. M., Fan, X., Sofka, A., \& Hunt, A. (2009). Accelerating preschoolers' early literacy development through classroom-based teacher-child storybook reading and explicit print referencing. Language, Speech, and Hearing Services in Schools, 40, 67-85.

Kazakoff, E. R. (2014). Toward a theory-predicated definition of digital literacy for early childhood. Journal of Youth Development, 9(1), 41-58.

Lafton, T. (2015). Digital literacy practices and pedagogical moments: Human and nonhuman intertwining in early childhood education. Contemporary Issues of Early Childhood, 16(2), 142-152.

Leppänen, U., Niemi, P., Aunla, K., \& Nurmi, J. E. (2004). Development of reading skills among preschool and primary school pupils. Reading Research Quarterly, 39(1), $72-$ 93.

Lindahl, M. G., \& Folkesson, A. M. (2012). ICT in preschool: Friend or foe? The significance of norms in a changing practice. International Journal of Early Years Education, 20(4), 422-436.

Lindberg, I. (2011). Fostering multilingualism in Swedish schools: Intensions and realities. In R. Källström, \& I. Lindberg (Eds.), Young urban Swedish: Variation and change in multilingual settings, (pp. 149-172). Göteborgs universitet: Göteborgsstudier i nordisk språkvetenskap 14 . 
Magnusson, M. (2013). Skylta med kunskap: En studie av hur barn urskiljer grafiska symboler i hem och förskola. [Signing with knowledge: A study of how children discern graphical symbols at home and in preschool]. (Doctoral dissertation). Göteborg, Kompendiet AB. 187.

Magnusson, M., \& Pramling, N. (2017). In 'Numberland': Play-based pedagogy in response to imaginative numeracy. International Journal of Early Years Education, 1-18.

Margrain, V., \& Mellgren, E. (2015). Akobarn: Development of a New Zealand-Sweden early years teaching-research collaboration. Early Education, 57, 7-11.

Martins, M. A., Albuquerque, A., Salvador, L., \& Silva, C. (2013). The impact of invented spelling on early spelling and reading. Journal of Writing Research, 5, 215-237.

Merchant, G. (2008). Digital Writing in Early Years. In J. Coiro, M. Knobel, C. Lankshear, \& D. J. Leu (Eds.), Handbook of research on new literacies (pp. 751-773). London: Routledge.

Melby-Lervåg, M., \& Lervåg, A. (2014). Reading comprehension and its underlying components in second-language learners: A meta-analysis of studies comparing firstand second-language learners. Psychological Bulletin, 140(2), 409-433.

Mellgren, E., \& Margrain, V. (2015). Student teacher views of text in early learning environments: Images from Sweden and New Zealand. Early Child Development and Care, 185(9), 1528-1544.

National Early Literacy Panel. (2008). Developing early literacy: Report of the national early literacy panel 2008. Washington, DC: National Institute for Literacy.

Neuman, S. B., \& Roskos, K. (1992). Literacy objects as cultural tools: Effects on children's literacy behaviors in play. Reading Research Quarterly, 27(3), 202-225.

Niikko, A., \& Havu-Nuutinen, S. (2009). In search of quality in Finnish pre-school education. Scandinavian Journal of Educational Research, 53(5), 431-445.

Norwegian Media Autority. (2014). Foreldre om småbarns mediabruk [Parents on young children's use of media]. Retrieved from https://www.medietilsynet.no/globalassets/publikasjoner/2015/rapport_foreldre_smab arns_mediebruk_2014.pdf

Norwegian Ministry of Education (2017). Preschool curriculum. Retrieved from https://lovdata.no/dokument/SF/forskrift/2017-04-24-487 
OECD. (2016). Starting strong IV. Early childhood education and care data country note:

Finland. Paris: OECD publishing. Retrieved from:

https://www.oecd.org/edu/school/ECECDCN-Finland.pdf

OECD. (2017). Reading performance (PISA) (indicator). Retrieved from:

https://data.oecd.org/pisa/reading-performance-pisa.htm.

Ouellette, G., \& Sénéchal, M. (2008). Pathways to literacy: A study of invented spelling and its role in learning to read. Child Development, 79(4), 899-913.

Palaiologou, I. (2016). Teachers' dispositions towards the role of digital devices in play-based pedagogy in early childhood education. Early Years, 36(3), 305-321.

Roskos, K., \& Neuman, S. (2011). The classroom environment: First, last and always. Reading Teacher, 65(2), 110-114.

Säljö, R. (2006). Laring og kulturelle redskaper. Om laereprosesser og den kollektive hukommelsen [Learning and cultural tools. Learning processes and the collective memory]. Oslo: J.W. Cappelens Forlag AS.

Simonsson, M. (2004). Bilderboken i förskolan: En utgångspunkt för samspel. [The picture book in preschool: A basis for interaction]. Linköping: Linköpings universitet.

Sommer, D., Pramling Samuelsson, I., \& Hundeide, K. (2011). Child perspectives and children's perspectives in theory and practice. Dordrech: Springer.

Statistics Finland. (2017). Language according to age and sex by region 1990 - 2016.

Retrieved from http://www.stat.fi/til/vaerak/2016/vaerak_2016_2017-03-

29_kuv_003_sv.html

Statistics Norway. (2016). Kindergartens, 2016, final figures. Retrieved from https://ssb.no/en/utdanning/statistikker/barnehager

Suoninen, A. (2013). Lasten mediabarometri 2013. 0-8 vuotiaiden mediankäyttö ja sen muutokset vuodesta 2010. [Children's media barometer 2013. 0-8-year-olds' media usage and its changes since 2010.] Helsinki: Nuorisotutkimusseura. Retrieved from: http://www.nuorisotutkimusseura.fi/images/julkaisuja/lastenmediabarometri2013.pdf

Svensson, A. K. (1993). Tidig språkstimulering av barn. [Children’s early language stimulation]. Lund: Almqvist och Wiksell.

Svensson, A. K. (2009). Högläsning i förskola och förskoleklass - hur vanligt är det? [Reading aloud in preschool and kindergarten - how common is it?] Borås: Institutionen för pedagogik. 
Swedish Media Council. (2017). Småungar \& medier 2017 [Kids \& media 2017]. Retrieved from:

https://statensmedierad.se/download/18.30c25b3115c152ee8f82fe95/1495204277588/ Småungar\%20och\%20medier\%202017\%20tillgänglighetsanpassad.pdf

Swedish Ministry of Education. (2016a). Kvalitetsdeklaration. Förskola: Barn och personal per 15 oktober. [Quality declaration. Preschool: Children and staff as of 15 October]. Stockholm: Sveriges officiella statisitik. Retrieved from: http://www.skolverket.se/statistik-och-utvardering/statistik-i-tabeller/forskola/barnoch-grupper

Swedish Ministry of Education, (2016b). Läroplan för förskolan Lpfö98. Reviderad 2016. [Curriculum for the pre-school Lpfö98: Revised 2016]. Stockholm: Fritzes.

Swedish school inspectorate (2017). Förskolans arbete med flerspråkiga barns språkutveckling. [Preschool's work with language development in multilingual children]. Retrieved from: https://www.skolinspektionen.se/sv/Beslut-ochrapporter/Publikationer/Granskningsrapport/Kvalitetsgranskning/forskolans-arbetemed-flersprakiga-barns-sprakutveckling/

Sylva, K., Chan, L. L. S., Melhuish, E., Sammons, P., Siraj-Blatchford, I., \& Taggart, B. (2011). Emergent literacy environments: Home and preschool influences on children's literacy development. In S. B. Neuman, \& D. K. Dickinson (Eds.), Handbook of early literacy research (Vol. 3.) (pp. 97-117). New York, NY: The Guilford Press.

Teale, W. H., \& Sulzby, E. (1986). Emergent literacy as a perspective for looking at how children becomes writers and readers. In W. H. Teale, \& E. Sulzby (Eds.), Emergent literacy: Writing and reading (pp. vii-xxv). Norwood, NJ: Ablex.

Torpsten, A. (2011). Global citizenship and lingual identity: The ability to perform in different lingual settings. Citizenship, Social and Economics Education, 10, 37-45.

Vallberg Roth, A-C. (2014). Nordic comparative analysis of guidelines for quality and content in early childhood education. Nordic Early Childhood Education Research Journal, $8(1), 1-35$.

Wessels, B. (2007). Inside the digital revolution. Policing and changing communication with the public. Hampshire: Ashgate.

Whitehurst, G. J., \& Lonigan, C. J. (1998). Child development and emergent literacy. Child Development, 69(3), 848-872. 
Wohlwend, K. E. (2009). Mapping multimodal literacy practices through mediated discourse analysis: Identity revision in What Not to Wear. National Reading Conference Yearbook 58, 66-81.

Worthington, M., \& van Oers, B. (2017). Children's social literacies: Meaning making and the emergence of graphical signs and texts in pretence. Journal of Early Childhood Literacy, 17(2), 147-175. 


\section{Appendix I}

\section{Observation Protocol}

\section{Part I}

Number of children in the preschool classroom:

Age group:

Number of preschool teachers: Number of childcare workers:

Number of assistant teachers/others:

\section{Part II}

\section{Reading and books}

1. To how many books do children have direct access?

2. The books are visibly displayed

3. The children have access to digital devices

4. There is a reading area sheltered from loud and gross motor play

5. There are audiobooks to which children can listen

$\square$ yes $\square$ no
$\square$ yes $\square$ no
$\square$ yes $\square$ no
$\square$ yes $\square$ no

\section{Print environment and writing}

1. The alphabet is visibly displayed in the preschool classroom

2. There are signs on shelves, cabinets and drawers

3. The children's names are placed on the wardrobe

4. Graphical symbols (smileys, numbers) are displayed on the walls

5. The classroom has a writing centre

$\square$ yes $\square$ no
$\square$ yes $\square$ no
$\square$ yes $\square$ no
$\square$ yes $\square$ no
$\square$ yes $\square$ no

\section{Multilingual children}

1. Are there multilingual children in the classroom?

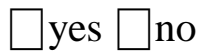

2. How many multilingual children are there?

3. There is text in language other than the language of instruction

4. There are books in languages other than the language of instruction How many such books are there?

5. Additional language teaching is offered in the language of instruction

6. Instruction is offered in the children's first language 
Table 1. The quantities of preschool staff

\begin{tabular}{lcccccc}
\hline & \multicolumn{2}{c}{ Sweden } & \multicolumn{2}{c}{ Norway } & \multicolumn{2}{c}{ Finland } \\
\cline { 2 - 7 } & $M$ & $S D$ & $M$ & $S D$ & $M$ & $S D$ \\
\hline Preschool teachers & 2.5 & 1.0 & 1.5 & .63 & 1.4 & .70 \\
\hline Childcare workers & 1.1 & .89 & 0.9 & .98 & 1.4 & .74 \\
Preschool teacher assistant & 0.6 & .88 & 2.1 & .92 & 1.1 & .89 \\
\hline
\end{tabular}

Note. Preschool teacher assistant $=$ untrained staff member. 
Table 2. The occurrence of early literacy artefacts in the three samples

\begin{tabular}{|c|c|c|c|c|c|c|c|c|}
\hline & \multicolumn{2}{|c|}{$\begin{array}{c}\text { Total } \\
(n=131)\end{array}$} & \multicolumn{2}{|c|}{$\begin{array}{l}\text { Sweden } \\
(n=35)\end{array}$} & \multicolumn{2}{|c|}{$\begin{array}{l}\text { Norway } \\
(n=45)\end{array}$} & \multicolumn{2}{|c|}{$\begin{array}{l}\text { Finland } \\
(n=51)\end{array}$} \\
\hline & $f$ & $S D$ & $f$ & $S D$ & $f$ & $S D$ & $f$ & $S D$ \\
\hline Visible books & $125(95 \%)$ & .21 & $35(100 \%)$ & .00 & $41(91 \%)$ & .29 & $49(96 \%)$ & .20 \\
\hline Audiobooks $^{1}$ & $63(51 \%)$ & .50 & $19(54 \%)$ & .51 & $26(58 \%)$ & .50 & $18(41 \%)$ & .50 \\
\hline Reading area & $62(47 \%)$ & .50 & $20(56 \%)$ & .50 & $21(47 \%)$ & .51 & $21(42 \%)$ & .50 \\
\hline Digital tools & $56(43 \%)$ & .50 & $22(63 \%)$ & .49 & $19(42 \%)$ & .50 & $15(29 \%)$ & .46 \\
\hline Alphabet & $89(68 \%)$ & .47 & $25(71 \%)$ & .49 & $34(75 \%)$ & .43 & $30(59 \%)$ & .50 \\
\hline Signs & $92(70 \%)$ & .46 & $13(37 \%)$ & .49 & $37(82 \%)$ & .39 & $42(82 \%)$ & .39 \\
\hline Name sign ${ }^{2}$ & $100(99 \%)$ & .10 & $35(100 \%)$ & .00 & $44(98 \%)$ & .15 & $21(100 \%)$ & .00 \\
\hline Symbols & $99(75 \%)$ & .43 & $24(69 \%)$ & .47 & $32(70 \%)$ & .45 & $43(84 \%)$ & .37 \\
\hline Writing center ${ }^{3}$ & $61(51 \%)$ & .50 & $26(74 \%)$ & .44 & $21(47 \%)$ & .51 & $14(35 \%)$ & .48 \\
\hline Books in $\mathrm{L1}^{4}$ & $15(14 \%)$ & .35 & $3(10 \%)$ & .31 & $8(19 \%)$ & .40 & $4(11 \%)$ & .32 \\
\hline Displayed text & $21(20 \%)$ & .40 & $9(29 \%)$ & .47 & $8(19 \%)$ & .40 & $4(11 \%)$ & .32 \\
\hline $\mathrm{L1}^{4}$ & & & & & & & & \\
\hline
\end{tabular}

Note. ${ }^{1}$ Missing data in Finnish sample $(n=44) .{ }^{2}$ Missing data in Finnish sample $(n=21) .{ }^{3}$ Missing data in Finnish sample $(n=40) .{ }^{4}$ Based on the classrooms with multilingual children, Swedish-Finnish bilingualism is not included. 
Table 3. Correlations between literacy artefacts in the preschools

\begin{tabular}{llcrrrrrrr}
\hline & $\mathbf{1}$ & $\mathbf{2}$ & $\mathbf{3}$ & $\mathbf{4}$ & $\mathbf{5}$ & $\mathbf{6}$ & $\mathbf{7}$ & $\mathbf{8}$ & $\mathbf{9}$ \\
\hline 1. Books & - & & & & & & & & \\
2. Visible books & $.23^{* *}$ & - & & & & & & \\
3. Audiobooks & .09 & .15 & - & & & & & \\
4. Reading area & .07 & .14 & $.18^{*}$ & - & & & & \\
5. Digital devices & .06 & .04 & $.36^{* *}$ & .14 & - & & & \\
6. Alphabet & -.02 & .34 & $.29 * *$ & .16 & $.20 *$ & - & & \\
7. Signs & .04 & -.02 & .03 & -.09 & -.11 & .02 & - & \\
8. Name signs & -.10 & -.02 & -.09 & .10 & .09 & .16 & -.07 & - \\
9. Symbols & $.28^{* *}$ & $.21^{*}$ & .12 & -.01 & .10 & .10 & .17 & -.06 & - \\
10. Writing centre & .04 & $.23^{* *}$ & .12 & $.26^{* *}$ & .10 & $.24 * *$ & -.13 & .11 & .10 \\
\hline Note. $* p>.05 ; * * p>.01$ & & & & & & & &
\end{tabular}

